Comunicação e Sociedade, vol. 12, 2007, pp. 234-236

\title{
0 papel da blogosfera no que resta da salvação
}

Luís Carmelo*

Austerlitz, Os Emigrantes e sobretudo a História Natural da Destruição ${ }^{1}$ são obras do escritor W. G. Sebald que nos permitem penetrar nos labirintos de uma amnésia colectiva. Não se trata, naturalmente, da amnésia colectiva que resulta do processamento dos dispositivos globais de carácter hipertecnológico (o território dos blogues), mas antes de um tabu histórico e, portanto, de uma amnésia forçada. Este tipo de elipses era - tê-lo-á sido quase sempre - próprio do véu que cobria geralmente os vencidos (hoje em dia, o fluxo global de imagens tende a esbater ambos os territórios: vencidos e vencedores parecem agora disputar um limbo de choque em tempo presumidamente real ${ }^{2}$ ). O caso da deliberada omissão histórica do que foi a radical destruição da Alemanha no final da II Grande Guerra Mundial tem sido, nas obras de Sebald, abordada de um modo descomprometido, desideologizado, memorial, frio e literariamente possante. Com efeito, o processo de contínua e implacável razia que conduziu à derrota do nazismo foi sempre tomado no pós-Guerra como um facto natural da própria lógica da guerra. As descobertas do horror nazi, na Primavera de 1945, tornaram incompreensível a própria ideia de guerra e de sentido (não da ausência, da falha ou da falta de sentido, mas do próprio sentido). O Holocausto era - e é ainda hoje em dia - a verdadeira impossibilidade ao vivo. Esse facto terá acelerado, e de que modo, a recusa alemã em reflectir sobre a urbanização do terror.

Como Sebald escreveu corajosamente, os alemães não se limitaram a adoptar esta «espantosa capacidade de auto-anestesia» que «parecia ter saído da guerra de extermínio sem males psíquicos dignos de nota». Para além disso, a própria "génese do milagre económico do pós-Guerra» teria mesmo tido como base este «catalisador puramente imaterial: uma torrente de energia psíquica que ainda hoje não secou e cuja nascente se encontra no segredo bem guardado dos cadáveres em que assentam as fundações» da Alemanha. Este segredo mereceu mais consistência e mais eficácia histórica, segundo o autor, do que qualquer outro "objectivo positivo", como por exemplo a "realização da democracia". Um tabu existe - e existirá sempre - como uma ferida para ser tocada. Sebald, nascido praticamente com o final da "Guerra" (ainda hoje continuamos a pronunciar “a Guerra”), teve esse arrojo. O início de Os Emigrantes ilustra, de modo tão doloroso quanto límpido, o significado de um exílio que parecia aliar a inevitabilidade à ausência de sentido. $\mathrm{O}$ "menino" e depois o "adolescente" assumem aí o pasmo

\footnotetext{
* Universidade Autónoma de Lisboa. luis.carmelo@sapo.pt

${ }^{1}$ Edições portuguesas da Teorema, Lisboa, respectivamente de 2004 (original de 2001), 2005 (Die Ausgewanderten. Vier lange Erzählungen, 2000) e 2006 (Luftkrieg und Literatur, 1999).

${ }^{2}$ Veja-se o impacto nos media (ao nível sobretudo das meta-ocorrências) do significado de termos como "vitória" e "derrota" na guerra de Julho e Agosto de 2006 que opôs o terrorismo do Hezbollah a Israel.
} 
de quem é arrancado de um inexplicável campo de cinzas mental, pacificado apenas pela silenciosa e sábia articulação entre a fuga para a frente e a amnésia compulsiva. Mesmo em tempos imemoriais, a memória foi sempre assegurada por narrativas bastante estáveis, embora de natureza muito diversa. Os mitos, por exemplo, nunca se confundiram com os chamados textos "sagrados". Estes últimos não podiam - e não podem - ser alterados e a sua razão de ser poucas vezes deixou de se confundir com um literalismo congénito. Ao invés, os mitos viviam - e vivem - de uma noção elástica de matriz, ou de ponto de partida, de tal forma - como escreveu H. Blumenberg em Trabalho sobre o Mito $\left(1979^{3}\right)$ - que é na relação entre "tema" e "variações" que o auditório e a emissão acabam por encontrar um sentido (um sentido fluido, mas que permanece como se propagasse uma evidência muito mais importante do que qualquer geometria canonizada pela memória). Os mitos aprenderam há muito a viver num mundo sem escrita que concedia à memória maior flexibilidade e mais margem de manobra, de inventividade e de recriação. A amnésia colectiva nos tempos míticos coincidia com aquele espaço difuso do vivido que nem sempre era agregado na narrativa (os vencidos apareceram, às vezes, nas narrativas míticas como é provado, por exemplo, na longa tradição da Sibila Tiburtina - evocadora dos feitos de Alexandre Magno). Segundo certos olhares contemporâneos, a modernidade nunca matou o mito, antes o incorporou e modelizou na voragem tecnológica, nas novas narrativas e na nova amplitude racional e subjectiva. Aliás, sobrevive ainda nos nossos dias um conjunto variado de práticas de base ne varietur (como o canto) que não relevam o perfil estático das narrativas fechadas. Também a reprodução mnemónica - como escreveu Le Goff - persiste nos nossos dias muito para além do literalismo. Actividades como o design perfilam-se na contemporaneidade como uma assunção clara entre a eficácia da cultura material (e da tecnologia) e a tradição artística que, de modo unívoco, sempre se reivindicou desde o Romantismo como herdeira única do mito. Os próprios blogues vivem deste pacto entre eficácia e criatividade, não deixando de repor ecos de ecos de muitas vozes na constituição da linguagem que diariamente agenciam. A superação das dicotomias estanques criadas pela modernidade (auditório-enunciação, verdade-sentido, público-privado, real-ficção, arte-técnica, mito-logos, etc.) é um dos teores do presente e é, sobretudo, um dos sinais que permitem caracterizar uma sociedade em transição para o paradigma hipertecnológico. Um dos sintomas mais constantes dos tempos actuais é a incidência do presente mais imediato nas nossas vidas. O presente tornou-se numa fixação mais ou menos hedonista e protética e distanciou-se do futuro e do passado através de dois muros espessíssimos (muros parecidos com o levantado, com alguma cativante euforia, por um personagem sacrificial de Paul Auster em A Música do Acaso). Os chamados "grandes ideais" abandonaram a tela ilusória e idílica do futuro (escatológica ou ideológica), enquanto as narrativas fixas eram subitamente substituídas por várias de raiz mundana - como

${ }^{3}$ Arbeit am Mythos. Tradução inglesa: Work on Myth, The MIT Press, Cambridge, Massachusetts, and London, England, 1990. 
as micronarrativas da blogosfera - que coexistem e se sucedem de modo meteórico. A revisitação quase sagrada do passado dava assim origem a um novo tipo de amnésia colectiva que ia transformando a memória baseada em narrativas estáveis numa espécie de Lost Highway. A metamorfose do saxofonista Fred Madison, no filme de Lynch, não é a mesma que delongadamente aparece em Orlando (Woolf), ou que, por absurdo, se enuncia através de Gregor Samsa (Kafka): nela o passado é uma remoção quase normal ao serviço de um "agora aqui" vertiginoso e sem inquietação de dúvidas, perguntas e explicações. A ficção cyberpunk vai mais longe neste passo que devora o território: sobra nela a ilusão da ilusão que mobiliza como protagonista o pós-homem criador de memórias diversas e jamais vividas (Bethke, Brunner, Burroughs, Cadigan, etc.). A virtualização surge aqui como essa enorme fábrica que confunde o implante com os efeitos que produz: a imagem corre na consciência e está noutros lados, ao mesmo tempo, dissociada da relação potência-acto. $\mathrm{O}$ acto e os tempos confundem-se. A amnésia instala-se e revê-se como uma normalidade. Desaparece assim de cena, definitivamente, aquele pasmo que Sebald evidenciara em Os Emigrantes. A virtualização tende a pôr à mostra todos os factos (mesmo os nunca vividos), ainda que sob a forma de simulações (imagens que reatam imagens e que se colocam todas ao mesmo nível no processamento global). Talvez seja por isso que as obras de Sebald convivem, hoje em dia, com um horizonte de expectativas que as sabe apreciar e respeitar. Vivemos num mundo onde tudo cabe, não porque tenhamos atingido um estado de perfeição, mas porque, de algum modo, regressámos ao coração do mitológico: embora num campo de micronarrativas instantanistas, a verdade é que voltámos a navegar entre a ambiguidade e a fluidez do sentido como se a comunicação global estivesse, a todo o momento, prestes a propagar uma evidência muito mais importante do que qualquer geometria canonizada pela memória.

Ao termos regressado a esta característica central do mito, elevámos a amnésia colectiva ao estatuto de troféu e fizemos das linguagens - sobretudo na rede e, também, nos blogues - um modo de dizer permanente que encontra na actualização disseminada, e não num qualquer ponto da narrativa, o seu clímax e a sua anunciação. Enquanto Sebald reivindicava a restituição da narrativa para enquadrar a vida num conjunto de sentidos, a rede e a casa blogosférica preferem cumprir a ininterrupta enunciação de narrativas e transformam esse acto num conjunto de sentidos que simula todo o tipo de enquadramentos e de reivindicações.

Estar on é, nos dias de hoje, estar salvo. Eis, por outras palavras, o que significa a euforia que tem atravessado a individualização (aparentemente) quase sem mediações que se edita e difunde diariamente na blogosfera. 